ISSN 0258-7122 (Print), 2408-8293 (Online)

Bangladesh J. Agril. Res. 43(2): 205-210, June 2018

\title{
NUTRIENT MANAGEMENT ON THE GROWTH AND YIELD OF BLACK CUMIN (NIGELLA SATIVA L.)
}

\author{
M. N. YOUSUF ${ }^{1}$, A. J. M. S. KARIMㄹ ${ }^{2}$ A. R. M. SOLAIMAN ${ }^{3}$ \\ M. S. ISLAM ${ }^{4}$ AND M. ZAKARIA ${ }^{5}$
}

\begin{abstract}
A field experiment was carried out at the research field of Bangabandhu Sheikh Mujibur Rahman Agricultural University (BSMRAU), Gazipur, during rabi (winter) season of 2016-17 to evaluate the effects of fertilizer treatments on black cumin (BARI Kalozira-1). The field belongs to Shallow red-brown terrace soil of Salna series under AEZ-28 (Madhupur Tract). The experiment was laid out in randomized complete block design (RCBD) with three replications. Results showed that the application of nutrient elements had positive effect on plant height, branches per plant, capsule setting, umbels per plant, capsules per plant, capsule size, seeds per capsule, 1000-seed weight and seed yield of black cumin. The highest seed yield $\left(1277 \mathrm{~kg} \mathrm{ha}^{-1}\right)$ was obtained from $75 \%$ RDCF + $25 \%$ cowdung- $\mathrm{N}$ treatment followed by $100 \%$ RDCF $\left(\mathrm{N}_{80} \mathrm{P}_{45} \mathrm{~K}_{50} \mathrm{~S}_{20} \mathrm{Zn}_{5} \mathrm{~B}_{2} \mathrm{~kg}\right.$ ha $\left.{ }^{1}\right)$ and the lowest seed yield (420 $\left.\mathrm{kg} \mathrm{ha}^{-1}\right)$ was recorded with 50\% RDCF. Thus, the IPNS treatment $75 \%$ RDCF $+25 \%$ cowdung-N appeared to be the best suitable package for black cumin cultivation in this location.
\end{abstract}

Keywords: Black cumin, IPNS, seed yield.

\section{Introduction}

Black cumin (Nigella sativa L.), belongs to the butter cup family Ranunculaceae (diploid, $2 \mathrm{n}=12$ ) and it has remarkable aromatic and medicinal properties. The black cumin seeds and oil have commercial significance as spice and medicines. Black cumin is generally short-lived annual herb originated in the Mediterranean region and it is widely cultivated throughout the South Europe, North Africa, countries of Middle East, Turkey, Iran, China, Japan and India Sub-Continent (Rana et al., 2012; Bhutia et al., 2015). In Bangladesh, it covers 14742 hectares of land, with total annual production of 16526 tons (DAE, 2017), over the Faridpur, Sariatpur, Madaripur, Pabna, Sirajganj, Jessore, Kushtia, Bogra, Rangpur and Natore districts (Ali et al., 2015; Noor et al., 2008). The average yield of black cumin is low which might be due to disease and insect infestation, weak nutrient management (Bhutia et al., 2015).

A plant nutritional constraint often restricts yield and qualities of crops. Application of cowdung along with chemical fertilizers improves soil health for the production of subsequent crops (Najm et al., 2012). Al-Saadi and Alhalabi (2012)

${ }^{1} \mathrm{PhD}$ (fellow), ${ }^{2,3 \& 4}$ Professors, Department of Soil Science, ${ }^{5}$ Professor, Department of Horticulture, Bangabandhu Sheikh Mujibur Rahman Agricultural University (BSMRAU), Gazipur-1706, Bangladesh. 
reported that application of NPK fertilizers increased yield of black cumin. According to Rana et al. (2012), application of $\mathrm{N}_{60} \mathrm{P}_{120} \mathrm{~kg}^{-1}$ have the maximum growth, yield and quality of black cumin with the highest net return per hectare. Girma and Taddesse (2013) found that application of $100 \mathrm{~kg} \mathrm{~N}$ and $50 \mathrm{~kg} \mathrm{P}_{2} \mathrm{O}_{5} \mathrm{ha}^{-1}$ gave maximum dry matter yield, seed yield and essential oil yield of white cumin. Pariari et al. (2012) reported that in Gangetic alluvial plains NAA at $100 \mathrm{ppm}$ with $\mathrm{N}_{30} \mathrm{P}_{40} \mathrm{~K}_{45} \mathrm{~kg} \mathrm{ha}^{-1}$ and FYM @ $15 \mathrm{t} \mathrm{ha}^{-1}$ gave the maximum seed yield of black cumin. Ali et al. (2015a) reported that the dry matter weight, number of primary branches, number of fruits, 1000-seed weight and seed yield of black cumin genotypes were significantly influenced by different levels of N-P-K fertilizers. The present study was therefore, done to see the response of black cumin to chemical fertilizers and cowdung application in AEZ-28 (Madhupur Tract) soil.

\section{Materials and Methods}

The field experiment was conducted at the research field of Bangabandhu Sheikh Mujibur Rahman Agricultural University (BSMRAU), Gazipur. The experimental field represents on Shallow red-brown terrace soil of Salna series (Plinthic Paleustult) under AEZ-28 (Madhupur Tract). The experiment was set up during rabi (winter) season of 2016-17. The geographic coordinates of the experimental location is $24^{\circ} 09^{\prime}$ North Latitude and $90^{\circ} 26^{\prime}$ East Longitude with an elevation of $8.2 \mathrm{~m}$ from mean sea level. A description of soil physical and chemical properties of the experimental field is presented in Table 1.

Table 1. Soil properties of the experimental field

\begin{tabular}{|c|c|c|c|c|c|c|c|c|c|c|c|c|c|}
\hline \multirow{2}{*}{ Texture } & \multirow{2}{*}{$\mathrm{pH}$} & \multirow{2}{*}{$\begin{array}{l}\mathrm{OC} \\
(\%)\end{array}$} & $\mathrm{Ca}$ & $\mathrm{Mg}$ & K & $\begin{array}{c}\text { Total } \\
\mathrm{N}\end{array}$ & $\mathrm{P}$ & S & B & $\mathrm{Zn}$ & $\mathrm{Cu}$ & $\mathrm{Mn}$ & Mo \\
\hline & & & \multicolumn{3}{|c|}{$\begin{array}{l}\text { (meq } 100 g^{-1} \\
\text { soil) }\end{array}$} & $\%$ & \multicolumn{7}{|c|}{$\left(\mu \mathrm{g} \mathrm{g}^{-1}\right.$ soil $)$} \\
\hline $\begin{array}{l}\text { Silty } \\
\text { clay } \\
\text { loam }\end{array}$ & 6.2 & 0.86 & 1.6 & 0.71 & 6.0 & 0.09 & 10.2 & 12 & 0.28 & 0.9 & 0.7 & 8.0 & 0.05 \\
\hline
\end{tabular}

The experiment was set up in a randomized complete block design (RCBD) with seven treatment combinations having three replications. The treatments were $\mathrm{T}_{1}$ $=100 \% \operatorname{RDCF}\left(\mathrm{N}_{80} \mathrm{P}_{45} \mathrm{~K}_{50} \mathrm{~S}_{20} \mathrm{Zn}_{5} \mathrm{~B}_{2} \mathrm{~kg} \mathrm{ha}^{-1}\right), \mathrm{T}_{2}=75 \% \mathrm{RDCF}+25 \% \mathrm{~N}$ from cowdung, $\mathrm{T}_{3}=50 \% \mathrm{RDCF}+50 \% \mathrm{~N}$ from Cowdung, $\mathrm{T}_{4}=150 \%$ RDCF, $\mathrm{T}_{5}=$ $125 \% \mathrm{RDCF}, \mathrm{T}_{6}=75 \% \mathrm{RDCF}$ and $\mathrm{T}_{7}=50 \%$ RDCF; RDCF means recommended dose of chemical fertilizers. The whole amount of cowdung, TSP, MoP, gypsum, zinc oxide and boric acid was applied as basal and $1 / 3^{\text {rd }}$ urea was applied in three equal at $5^{\text {th }}, 9^{\text {th }}$ and $11^{\text {th }}$ week after sowing. The seeds of black cumin cv. BARI Kalozira-1 were sown on 22 November 2016 in $2.5 \mathrm{~m}$ x $2.0 \mathrm{~m}$ plot at line to line distance $20 \mathrm{~cm}$. Seeds were soaked in water for 24 hours to facilitate germination, then the seeds dried and treated with Bavistin (carbendazim) @ $2 \mathrm{~g} \mathrm{~kg}^{-1}$ seeds to minimize the primary seed-borne disease. The 
seeds were mixed with some loose soil to allow uniform sowing in rows @ $10 \mathrm{~kg}$ $\mathrm{ha}^{-1}$ at a depth of about one $\mathrm{cm}$. The seeds were covered with loose soil properly just after sowing and gently pressed by hands with slight watering to enhance proper germination. Continuous sowing was done to maintain plant to plant distance of $10 \mathrm{~cm}$ by thinning after 25 DAS. Intercultural operations (four irrigations, three weeding and three times' spray of Bavistin @ $2 \mathrm{~g} \mathrm{~L}^{-1}$ of water spray for controlling damping off disease) were done in the whole cropping period. Observations were done on the growth parameters like plant height and number of branches at 100 DAS. The crops were harvested on 20 March 2017, when as around $50-60 \%$ of the capsules turned into straw color from green. Ten plants were selected randomly from each plot for counting some growth and yield parameters. The harvested plants were sun dried for four days and threshing was done by beating with sticks. The seeds were winnowed and cleaned for recording data. The seed yield per plot was recorded from $1 \mathrm{~m}^{2}$ area and then converted to yield per hectare. The data were subjected to statistical analysis by using MSTAT software to find out the significance of variation between treatments. The difference between treatment means were judged by Duncan's Multiple Range Test (DMRT) according to Gomez and Gomez (1984).

\section{Results and Discussion \\ Plant height}

Fertilizer treatments significantly affected the plant height (Table 2). The tallest plant $(65 \mathrm{~cm})$ was recorded in treatment $\mathrm{T}_{2}(75 \% \mathrm{RDCF}+25 \% \mathrm{~N}$ from cowdung) and the smallest plant $(23.4 \mathrm{~cm})$ was noted in treatment $\mathrm{T}_{7}(50 \% \mathrm{RDCF})$. Similar results were reported by (Ali et al., 2015a, b).

\section{Number of branches per plant}

As shown in the Table 2, there was significant difference in number of branches per plant between the treatments, the maximum number of branches per plant (6.7) in treatment $\mathrm{T}_{2}\left(75 \% \mathrm{RDCF}+25 \% \mathrm{~N}\right.$ from cowdung) followed by treatment $\mathrm{T}_{1}$, $\mathrm{T}_{5}$. The minimum number of branches per plant (4.07) was found in the treatment $\mathrm{T}_{7}$ (50\% RDCF). Additional amount of nutrient applications increased the number of branches which ultimately contributed to the formation of additional number of capsules per plant. Thus, these parameters could be used as good indicators of improving yield potential in black cumin. These results are in agreement with the research findings of Tuncturk et al. (2013) and Bhutia et al. (2015).

\section{Days to capsule setting}

Table 2 shows that the maximum days (70.7) to capsule setting was required in treatment $\mathrm{T}_{2}(75 \% \mathrm{RDCF}+25 \% \mathrm{~N}$ from cowdung) and the minimum days (63.3) in the treatment $\mathrm{T}_{7}(50 \% \mathrm{RDCF})$. These results indicated that early capsule setting occurred in the plants which were inadequately supplied with nutrients. 


\section{Number of umbellets per plant}

The number of umbellets per plant (Table 2) differed significantly due to variation in application of nutrient treatments. The maximum number of umbellets per plant (67.7) was found with application of $75 \% \mathrm{RDCF}+25 \% \mathrm{~N}$ from cowdung, while the minimum number of umbellets per plant (31.7) in application of 50\% RDCF. The number of umbellets per plant directly influenced the number of capsules per plant. This was probably due to adequate nutrient uptake by plant by resulting in production of more branches as well as more number of umbellets per plant. Rana et al. (2012) and Ali et al. (2015b) reported similar results.

Table 2. Effects of nutrient management on the growth of black cumin

\begin{tabular}{c|c|c|c|c|c}
\hline Treatment & $\begin{array}{c}\text { Plant height } \\
(\mathrm{cm})\end{array}$ & $\begin{array}{c}\text { No. of } \\
\text { branches per } \\
\text { plant }\end{array}$ & $\begin{array}{c}\text { Days to } \\
\text { capsule } \\
\text { setting }\end{array}$ & $\begin{array}{c}\text { No. of } \\
\text { umbellets per } \\
\text { plant }\end{array}$ & $\begin{array}{c}\text { No. of } \\
\text { capsules per } \\
\text { plant }\end{array}$ \\
\hline $\mathrm{T}_{1}$ & $58.8 \mathrm{~b}$ & $6.20 \mathrm{ab}$ & $66.3 \mathrm{~cd}$ & $62.9 \mathrm{~b}$ & $55.5 \mathrm{~b}$ \\
$\mathrm{~T}_{2}$ & $65.0 \mathrm{a}$ & $6.70 \mathrm{a}$ & $70.7 \mathrm{a}$ & $67.7 \mathrm{a}$ & $58.9 \mathrm{a}$ \\
$\mathrm{T}_{3}$ & $53.6 \mathrm{c}$ & $5.40 \mathrm{~b}$ & $68.0 \mathrm{~b}$ & $58.9 \mathrm{c}$ & $56.9 \mathrm{ab}$ \\
$\mathrm{T}_{4}$ & $45.5 \mathrm{e}$ & $5.30 \mathrm{bc}$ & $67.3 \mathrm{bc}$ & $53.7 \mathrm{~d}$ & $38.8 \mathrm{c}$ \\
$\mathrm{T}_{5}$ & $47.7 \mathrm{~d}$ & $6.17 \mathrm{ab}$ & $68.0 \mathrm{~b}$ & $61.7 \mathrm{bc}$ & $54.6 \mathrm{~b}$ \\
$\mathrm{~T}_{6}$ & $37.1 \mathrm{f}$ & $4.40 \mathrm{~cd}$ & $65.7 \mathrm{~d}$ & $39.9 \mathrm{e}$ & $34.2 \mathrm{~d}$ \\
$\mathrm{~T}_{7}$ & $23.4 \mathrm{~g}$ & $4.07 \mathrm{~d}$ & $63.3 \mathrm{e}$ & $31.7 \mathrm{f}$ & $26.2 \mathrm{e}$ \\
\hline $\mathrm{CV}(\%)$ & 2.33 & 9.84 & 0.93 & 3.54 & 3.20 \\
\hline
\end{tabular}

Legend: $\mathrm{T}_{1}=100 \% \operatorname{RDCF}\left(\mathrm{N}_{80} \mathrm{P}_{45} \mathrm{~K}_{50} \mathrm{~S}_{20} \mathrm{Zn}_{5} \mathrm{~B}_{2} \mathrm{~kg} / \mathrm{ha}\right), \mathrm{T}_{2}=75 \% \mathrm{RDCF}+25 \% \mathrm{~N}$ from Cowdung, $\mathrm{T}_{3}=50 \% \mathrm{RDCF}+50 \% \mathrm{~N}$ from Cowdung, $\mathrm{T}_{4}=150 \%$ RDCF, $\mathrm{T}_{5}=125 \%$ RDCF, $\mathrm{T}_{6}=75 \% \mathrm{RDCF}$ and $\mathrm{T}_{7}=50 \% \mathrm{RDCF}$

\section{Number of capsules per plant}

Table 2 exhibits that the maximum number of capsules (58.9) per plant was produced by treatment $\mathrm{T}_{2}$ where nutrients were applied as $75 \% \mathrm{RDCF}+25 \% \mathrm{~N}$ from cowdung and the minimum results (26.2 capsules per plant) in $\mathrm{T}_{7}$ representing 50\% RDCF. Total number of capsules per plant appeared to be the most important component since it is closely related with seed yield. Increase in number of capsules per plant indicates production of more number of flowers per umbel, higher percentage of capsule set and reduced shedding of flowers and capsules which resulted in increased yield. Tuncturk et al. (2013) and Rana et al. (2012) also recorded similar results.

\section{Capsule size}

Capsule size is represented by the length and diameter of the capsule (Table 3 ). The mean maximum length $(1.43 \mathrm{~cm})$ and diameter $(1.67 \mathrm{~cm})$ of single capsule was observed in treatment $T_{2}$, while the minimum length $(0.63 \mathrm{~cm})$ and diameter $(0.67 \mathrm{~cm})$ of capsule was found in treatment $\mathrm{T}_{7}$. Capsule size directly affects the number of seeds per capsule which in turn impacted yield. Bigger size capsule had higher number of seeds. 


\section{Number of seeds per capsule}

The Table 3 shows that number of seeds per capsule was affected by the fertilizer treatments. The highest number of seeds per capsule (111.9) was obtained when nutrient elements were applied as $75 \% \mathrm{RDCF}+25 \% \mathrm{~N}$ from cowdung and the lowest number of seeds per capsule (70.2) was observed with 50\% RDCF. The results are in agreement with the research findings of Ghanepasand et al. (2014) and Bhutia et al. (2015).

Table 3. Effects of nutrient management on the yield and yield components of black cumin

\begin{tabular}{|c|c|c|c|c|c|}
\hline \multirow[b]{2}{*}{ Treatment } & \multicolumn{2}{|c|}{ Capsule size } & \multirow{2}{*}{$\begin{array}{l}\text { No. of seeds } \\
\text { per capsule }\end{array}$} & \multirow{2}{*}{$\begin{array}{l}1000 \text {-seed } \\
\text { weight }(\mathrm{g})\end{array}$} & \multirow{2}{*}{$\begin{array}{l}\text { Seed yield } \\
\left(\mathrm{kg} \mathrm{ha}^{-1}\right)\end{array}$} \\
\hline & $\begin{array}{c}\text { Capsule } \\
\text { length }(\mathrm{cm})\end{array}$ & $\begin{array}{c}\text { Capsule } \\
\text { diameter }(\mathrm{cm})\end{array}$ & & & \\
\hline $\mathrm{T}_{1}$ & $1.23 \mathrm{a}$ & $0.97 \mathrm{~b}$ & $96.33 b$ & $2.47 b$ & $1150.0 \mathrm{~b}$ \\
\hline $\mathrm{T}_{2}$ & $1.43 \mathrm{a}$ & $1.67 \mathrm{a}$ & $111.9 \mathrm{a}$ & $2.67 \mathrm{a}$ & $1277.0 \mathrm{a}$ \\
\hline $\mathrm{T}_{3}$ & $1.27 \mathrm{a}$ & $0.97 b$ & $94.53 b$ & $2.40 \mathrm{bc}$ & $1043.0 \mathrm{c}$ \\
\hline $\mathrm{T}_{4}$ & $1.27 \mathrm{a}$ & $0.87 b c$ & $75.47 \mathrm{~d}$ & $1.97 \mathrm{~d}$ & $593.7 \mathrm{e}$ \\
\hline $\mathrm{T}_{5}$ & $1.03 \mathrm{~b}$ & $0.80 \mathrm{c}$ & $84.07 \mathrm{c}$ & $2.27 \mathrm{c}$ & $656.7 \mathrm{~d}$ \\
\hline $\mathrm{T}_{6}$ & $0.90 \mathrm{~b}$ & $0.77 \mathrm{~cd}$ & $70.87 d$ & $1.77 \mathrm{e}$ & $500.2 f$ \\
\hline $\mathrm{T}_{7}$ & $0.63 c$ & $0.67 \mathrm{~d}$ & $70.20 \mathrm{~d}$ & $1.43 \mathrm{f}$ & $420.3 \mathrm{~g}$ \\
\hline $\mathrm{CV}(\%)$ & 9.29 & 7.98 & 3.90 & 4.55 & 4.02 \\
\hline
\end{tabular}

Legend: $\mathrm{T}_{1}=100 \% \mathrm{RDCF}\left(\mathrm{N}_{80} \mathrm{P}_{45} \mathrm{~K}_{50} \mathrm{~S}_{20} \mathrm{Zn}_{5} \mathrm{~B}_{2} \mathrm{~kg} / \mathrm{ha}\right), \mathrm{T}_{2}=75 \% \mathrm{RDCF}+25 \% \mathrm{~N}$ from Cowdung, $\mathrm{T}_{3}=50 \% \mathrm{RDCF}+50 \% \mathrm{~N}$ from Cowdung, $\mathrm{T}_{4}=150 \% \mathrm{RDCF}, \mathrm{T}_{5}=125 \%$ $\mathrm{RDCF}, \mathrm{T}_{6}=75 \% \mathrm{RDCF}$ and $\mathrm{T}_{7}=50 \% \mathrm{RDCF}$

\section{0-seed weight}

The weight of 1000 -seed was significantly affected by the fertilizer treatments (Table 3). The maximum 1000-seed weight $(2.67 \mathrm{~g})$ was recorded in treatment $\mathrm{T}_{2}$ and the minimum 1000 -seed weight $(1.43 \mathrm{~g})$ was noted in treatment $\mathrm{T}_{7}$. The 1000 seed weight can be affected by several factors such as variety, growing condition, climatic factors, soil properties and cultural and nutrient management. Similar results were obtained by Ghanepasand et al. (2014) and Ali et al. (2015b).

\section{Seed yield}

The data presented in Table 3 revealed that fertilizer treatments affected the seed yield of black cumin. The maximum seed yield $\left(1277 \mathrm{~kg} \mathrm{ha}^{-1}\right)$ was obtained when nutrients were applied as $75 \% \mathrm{RDCF}+25 \% \mathrm{~N}$ from cowdung and the minimum seed yield $\left(420 \mathrm{~kg} \mathrm{ha}^{-1}\right)$ in application of $50 \% \mathrm{RDCF}$. Similar results were recorded by Ali et al. (2015a, b) and Yousuf et al. (2014).

\section{Conclusion}

Fertilizer application played an important role on the growth and seed yield of black cumin. The fertilizer treatment $\mathrm{T}_{2}(75 \% \mathrm{RDCF}+25 \% \mathrm{~N}$ from cowdung) 
was observed as the best nutrient package for black cumin cultivation in Shallow Red-Brown Terrace Soil of Salna series under AEZ-28 (Madhupur Tract).

\section{References}

Ali, K.A., N.H. Rasoul, A. Sardar, S.A. Zaino, M.K.H. Abdulrahman and H.H. Hamad 2015a. Influence of foliar application of zinc on the growth, yield and essential oil content of black cumin (Nigella sativa L.). Zanco J. Pure Appl. Sci. 27(5): 7-12.

Ali, M.M.K., M.A. Hasan and M.R. Islam. 2015b. Influence of fertilizer levels on the growth and yield of black cumin (Nigella sativa L.). The Agriculturist. 13: 97-104.

Al-Saadi, A.J.H. and H.E.S. Alhalabi. 2012. The influence of cytokinin and NPK compound fertilizer on some yield components and active compound of (Nigella sativa L.) plant. J. Kerbala Uni. 10(2): 56-66.

Bhutia, K.C., S. Bhandari, R. Chatterjee, S.O. Bhutia and N. Gurung. 2015. Integrated micronutrient spray on yield assessment of black cumin (Nigella sativa) in Nadia district of West Bengal. J. Crop Weed 11 (Special Issue): 205-209.

DAE. 2017. Annual spices production report. Department of Agricultural Extension. Ministry of Agriculture. Khamarbari, Dkaka.

Ghanepasanda, F., G. Noormohamadi, M.R. Haj Seyed Hadi and M.T. Darzi. 2014. Influence of manure application and nitrogen fixing bacteria on yield and yield components of black cumin (Nigella sativa L.). Int. J. Adv. Biol. Biom. Res. 2(3): 628-635.

Girma, A. and M. Taddesse. 2013. Yield components, agronomic and essential oil yields of white cumin as affected by varying doses of nitrogen and phosphorous. Intl. J. Agron. Plant. Prod. 4(11): 3096-3102.

Gomez, K.A. and A.A. Gomez. 1984. Statistical Procedures for Agricultural Research $\left(2^{\text {nd }}\right.$ Ed.). John Wiley \& Sons, New York.

Najm, A.A., M.R. Haj Seyed Hadi, M.T. Darzi, A.R. Rahi and F. Fazeli. 2012. Effects of integrated management of nitrogen fertilizer and cattle manure on the leaf cholorophyll, yield and tuber glycoalkaloids of Agria potato. Commun. Soil Sci. Plant Anal. 43: 912-923.

Noor, S., M.S. Khan, N.C. Shil and M.R. Talukder. 2008. Integrated nutrient management for sustainable yield of major spices crops in Bangladesh. Bangladesh J. Agric. Environ. 4 (Special issue): 95-113.

Pariari, A., R. Chatterjee and S. Khan. 2012. Effect of $\mathrm{GA}_{3}$ and AAA on growth and yield of black cumin (Nigella sativa L.). J. Crop Weed 8(1): 165-166.

Rana, S., P.P. Singh, I.S. Naruka and S.S. Rathore. 2012. Effect of nitrogen and phosphorus on growth, yield and quality of black cumin (Nigella sativa L.). Intl. J. Seed Spices 2(2): 5-8.

Tuncturk, M., R. Tuncturk and B. Yıldırım. 2013. The effects of varying phosphorous doses on yield and some Yield Components of black cumin (Nigella sativa L.). Adv. Environ. Biol. 5(2): 371-374.

Yousuf, M.N., S. Brahma, M.M. Kamal, S. Akter and M.E.K. Chowdhury. 2014. Effect of nitrogen, phosphorus, potassium and sulphur on the growth and seed yield of coriander (Coriandrum sativum L.). Bangladesh J. Agril. Res. 39(2): 303-309. 